УДК 340.1

DOI: $10.14451 / 2.147 .7$

\title{
РЕАЛИЗАЦИЯ СОЦИАЛЬНОЙ ДОКТРИНЫ РИМСКО-КАТОЛИЧЕСКОЙ ЦЕРКВИ В ПОЛИТИКО-ПРАВОВОЙ СФЕРЕ (НА ПРИМЕРЕ ИТАЛИИ ПЕРВОЙ ТРЕТИ ХХ В.) *
}

\author{
(c) 2020 Дородонова Наталия Васильевна \\ кандидат юридических наук, доцент кафедры истории государства и права \\ Саратовская государственная юридическая академия, Россия, Саратов \\ E-mail: dorodonovan@gmail.com
}

В статье рассматривается содержание социальной доктрины римской католической церкви и ее влияние на развитие социального законодательства в Италии. Проводится анализ ряда нормативноправовых актов Италии первой трети XX в. на предмет отражения в них идей социального вопроса. Делается вывод, что концепция благотворительности в Италии не противоречила суверенитету социальной сферы, а для того, чтобы быть более эффективной, отвечала принципу справедливости.

Ключевые слова: католическая церковь, социальное учение, энциклика, история государства и права, Италия, субсидиарность, социальный католицизм, корпоративизм.

В современную эпоху «социальный вопрос» был вызван социально-экономическими и политическими преобразованиями, связанными с промышленной революцией и последующим процессом индустриализации с разным временным периодом и динамикой, с конца XVIII в.второй половины XX в. В конце XIX в. Италия объединилась из разнородных политических и социальных образований в единое государство. Формирование современных социальных государств было вопросом времени и темпов индустриализации, а Италия была «поздним» государством в этом отношении, т.к. промышленный рост пришелся только на последнюю четверть XIX в. А.Гершенкрон пишет, что Италия является примером «поздней» нации, развивающейся в условиях экономической отсталости [1]. Он отмечает, что темпы индустриализации в Италии в XIX в. были очень медленными.

Взгляд на доктрину социальной политики показывает еще один примечательный феномен: в Италии процесс развития католической социальной доктрины сильно отличался от других европейских стран. Католическая социальная мысль в начале XIX в. в Италии была сосредоточена на доминирующих принципах благотворительности и субсидиарности, заложенных в энциклике папы Льва XIII «Rerum Novarum» 1891 г. Безусловно, энциклика помогает итальянскому католицизму выйти из категорий средневекового корпоративизма. Как пишет в своей книге «Церковь и государство. Социологическое и историческое исследование» Луиджи Стурцо: «...несмотря на сопротивление переменам со стороны Папы и со стороны широких слоев католического мира, энциклика генерирует новый, широко распространяемый импульс среди духовенства и мирян, организовывающих союзы рабочих, профсоюзы, профессиональные училища и требующих справедливой заработной платы» [2]. Проблема милосердия больше не рассматривается в терминах милостыни - так ранее понимались помощь и благотворительность нуждающимся. Теперь благотворительность в Италии институционализирована, трансформируясь в структурированную, а не эпизодическую деятельность. Начиная со второй половины 1800-х годов система благотворительности в разных государствах Италии состояла из Operé Pie - обширной сети местных церковных благотворительных учреждений (около 20000), которая представляла собой фрагментированную, непрозрачную и зачастую коррумпированную систему социального обеспечения. Так как система отражала католические средневековые социальные идеи, то она являлась чрезвычайно важным инструментом социального контроля и политического влияния католической церкви Италии. В связи с чем, либералы, пришедшие к власти в королевстве Пьемонт-Сардиния в середине XIX в., имели достаточно оснований для реформирования существующей на тот момент социальной системы. Идея Бенсо ди Кавура, первого премьер-министра объединенного Сардин-

* Исследование выполнено при финансовой поддержке РФФИ в рамках научного проекта № 20-011-00673 
ского королевства, заключалась в том, чтобы создать государственную систему социального обеспечения, но его попытка была неудачной. Принятый впервые Закон № 753 от 3 августа 1862 г. [3] хоть и ввел дисциплинарные меры в отношении общественных благотворительных учреждений, но закрепил принцип автономии благочестивых учреждений и ограничил вмешательство государства в их деятельность. В соответствии с Законом № 753 в каждом муниципалитете королевства была создана «Конгрегация благотворительности» (Congregazioni di Carità) c целью надзора за предоставлением субсидий и льгот для бедных. Конгрегация благотворительности являлась некоммерческой организацией, финансируемой за счет частных пожертвований или завещаний, которая заботилась о бедных, сиротах, инвалидах, взяв на себя юридическое представительство в административных и судебных органах.

Функции и деятельность благотворительных организаций, а также методы управления были пересмотрены в 1890-91 гг. на основании Закона № 6972 от 17 июля 1890 г. [4], устанавливающего Положение о государственных благотворительных учреждениях («Закон Криспи»)», и последующий королевский Указ № 99 от 5 февраля 1891 г., которым было утверждено Положение о государственных благотворительных учреждениях [5]. «Закон Криспи» стал важной вехой в развитии социального обеспечения в Италии, поскольку представлял собой первый реальный разрыв монополии Церкви на оказание социальной помощи: был установлен полный государственный контроль над Operé Pie. Тем не менее, это не ознаменовало прихода в страну современной системы социального обеспечения, т.к., по сути, оставило нетронутой старую систему благотворительных учреждений. Лишь Законом № . 847 от 3 июня 1937 г. [6] благотворительные учреждения Operé Pie были ликвидированы, а их полномочия переданы новым «органам муниципальной помощи» (l'ente comunale di assistenza). Финансирование этих органов осуществлялось за счет доходов от активов, получаемых от государства или благотворительных организаций, находящихся в их управлении, а также за счет субсидий, ежегодно выделяемых государством. Органы муниципальной помощи должны были способствовать отправке нуждающихся детей в морские и горные колонии, оказывать помощь малоимущим, инвалидам в больницах, приютах, социальных учреждениях, детских домах и т.д.

Динамику «социального вопроса» в Италии можно проследить по взаимозависимости предложений, выдвинутых множеством социальных и институциональных субъектов, вовлеченных в процесс индустриализации, в свете различных и противоположных взглядов на экономические, социальные и политические отношения. В центре «социального вопроса» находится утверждение общественного представительства интересов рабочих через ассоциации, основанные на свободной солидарности трудящихся, как это исторически достигалось профсоюзами. Например, в 1874 г. было создано «Opera dei Congressi e dei comitati cattolici», политико-религиозное объединение, союз католических ассоциаций по совместной деятельности в области защиты прав церкви, религиозных и социальных интересов итальянцев, а также с целью поддержки публичного присутствия католической церкви в гражданском обществе. Opera dei Congressi объединит в течение тридцати лет под своей эгидой все экономические, социальные и политические инициативы итальянских католиков с конца XIX в. до начала XX в. Одним из идеологов Opera dei Congressi являлся Джузеппе Тониоло, разработавший собственную социологическую теорию, с преобладанием этики и христианского духа над законами экономики. Джузеппе Тониоло в одной из работ «Договор о социальной экономике», предложил решение социальной проблемы, которое отвергало как индивидуализм капиталистической системы, так и коллективизм, отстаиваемый социализмом, посредством создания промежуточных органов, настоящих корпораций, организованных иерархически и признанных государством [7]. В своих работах он внес многочисленные предложения по введению праздничных дней, ограничению рабочего времени, защите труда женщин и детей. В 1905 г. после роспуска Папой Римским Пием X Opera dei Congressi, были созданы три новых союза: Экономико-социальный союз («l'Unione economica-sociale»), Избирательный союз («l’Unione elettorale»), Народный союз («l'Unione popolare»).

В начале XX в. Церковь изучает новые области социального апостольства, например, создание «сельских банков» с целью «приучить к сбережению и борьбе с ростовщичеством». Вскоре появляются кооперативные организации (в 1910 г. существовали в 62 итальянских 
епархиях). Во время понтификата Бенедикта XV (1914-1922) преобладают социальные проблемы, возникшие в связи с началом Первой мировой войны. Папа Римский вносит два значительных изменения в социальные вопросы: с одной стороны, он побуждает духовенство взять на себя обязательство улучшить условия жизни рабочих, способствуя созданию независимых ассоциаций, с другой, признает легитимность христианского рабочего синдикализма в функциональном отношении и в противоположность социалистическому и коммунистическому. Таким образом, христианским работникам предоставляется свобода защищать свои законные экономические интересы, не нанося ущерба своим духовным и религиозным интересам.

В результате преобразований в экономике и производстве, вызванных Первой мировой войной, и социальных конфликтов сразу после нее (во время захвата земель и борьбы рабочих, кульминацией которых стало занятие заводов в 1920 г. в период «красного двухлетия»), проблема взаимосвязи социальной деятельности католиков с их политической деятельностью оставалась открытой. В 1918 г. была основана Итальянская конфедерация рабочих (Confederazione Italiana dei lavoratori), первая официальная христианская (католическая) профсоюзная организация в Италии, выступавшая за защиту социальных прав (обязательное страхование, равная зарплата для мужчин и женщин, сокращение рабочего дня) [8]. В 1917-1919 гг. социальные выплаты резко возросли. Была введена система страхования от безработицы для работников, занятых полный рабочий день, которая касалась частично и сельскохозяйственных работников. Наконец, были введены обязательные пенсии [9]. 20 февраля 1919 г. подписывается соглашение с Конфедерацией промышленников о сокращении рабочего времени до 8 часов в день и 48 часов в неделю (соглашение предусматривает, среди прочего, создание внутренних комиссий на каждом заводе; назначение комиссии по совершенствованию социального законодательства и реформированию заработной платы). Королевским декретом № 692 от 1923 г. (впоследствии Закон № 473 от 17 апреля 1925 г.) максимальное рабочее время в течение 8 часов в день или 48 в неделю было распространено на все категории (то же самое положение было связано с установкой ограничения также для работы сверхурочные соответственно по 2 часа в день и 12 часов в неделю) [10].

В 1922 г. фашистское движение, возглавляемое Муссолини, захватило власть в Италии [11]. Отношение католического мира к происходящему в значительной степени можно почерпнуть из энциклики «Quadragesimo anno», обнародованной Пием XI в 1931 г. к 40-летию «Rerum Novarum». В энциклике Пий XI принял фундаментальный выбор в пользу «эволюционного пути»: приверженность Церкви к религиозному формированию и деятельности общественных организаций; расширение организаций рабочих в форме профсоюзов; прогресс в законодательстве в пользу рабочих наряду с прямыми социальными вмешательствами. Пий XI призывал и к вмешательству государства, устанавливая при этом принцип субсидиарности в качестве основы для своих действий. Мировой опыт функционирования и развития социальноэкономических систем постоянно доказывает, что в критических, кризисных и неустойчивых ситуациях общественного развития, государственное регулирование социальных процессов возрастает, изменяется, приспосабливаясь к новым социально-экономическим формам [12].

Самый значительный скачок в истории развития итальянского социального государства до 1945 г. произошел во время мировых войн. Конечно, это совпало с массовой индустриализацией страны и военной мобилизацией. В конце Второй мировой войны католическая церковь смогла разработать действия по социальному восстановлению страны, играя важную роль в получении и управлении международной помощью, предназначенной для помощи беднейшим слоям населения и инициированию восстановления отечественного производства. Итальянское католичество, прежде всего, на уровне профсоюзов присоединилось к Итальянской конфедерации профсоюзов, неконфессиональной организации. Со своими многочисленными ассоциациями, светскими и религиозными, католический мир сопровождал превращение Италии в индустриальную страну с последующим возникновением новых трудностей, благоприятствуя образованию новых классов, разделяя их социальные потребности. Одна из возможностей для слияния социально-католической традиции с новыми вызовами в экономике появилась в июле 1943 г., когда неконфессиональное движение Azione Cattolica разработало кодекс Камальдоли (Codice di Camaldoli), манифест со- 
циального католицизма, планирующий экономическую политику [13]. Документ представлял собой заметный отход от господствовавшей до сих пор корпоративной идеи.

Признаки вызова классической позиции социального католицизма можно обнаружить и в первых политических заявлениях зарождающейся христианской демократии, в работе Альсидо де Гаспери «Реконструктивные идеи христианской демократии» (Idee ricostruttive della Democrazia cristiana) 1942-43 гг. [14] В своей политической линии католики должны были принять третью альтернативу капитализму и социализму, отстаиваемую в церковной доктрине. Настаивание на свободном членстве в профсоюзе и регулировании коллективных переговоров с обязательным арбитражем в трудовых спорах также было продиктовано недавним опытом [15].
Таким образом, в Италии после конфликтной фазы «социального вопроса» постепенное утверждение свободного профсоюзного движения позволило с большей ясностью очертить взаимосвязь между расширением демократического процесса и участием общества в формировании социально-экономических решений. В первой трети XX в. «социальный вопрос» не только не завершился эволюцией культуры труда и экономической динамикой глобального общества, но и характеризовался способностью субъектов гражданского общества ориентировать рыночную экономику на справедливость, что позволило очертить взаимосвязь между демократическим процессом и участием общества в формировании социально-экономических решений.

Исследование выполнено при финансовой поддержке РФФИ в рамках научного проекта № 20-011-00673

\section{Библиографический список}

1. Гершенкрон А. Экономическая отсталость в исторической перспективе. М., 2015. С. 110.

2. Sturzo L. Chiesa e Stato. Studio sociologico-storico. V. II. Bologna, 1959. P. 147.

3. URL: www.lombardiabeniculturali.it/archivi/profili-stituzionali/MIDL00021E/+\&cd=4\&hl=en\&ct=clnk\&gl=ru

4. Legge 17 luglio 1890, n. 6972 (in Gazz. Uff., 22 luglio, n. 171). Norme sulle istituzioni pubbliche di assistenza e beneficenza. URL: http://homepage.sns.it/pavan/Storia/Legge\%20Crispi\%201890.pdf

5. Regio decreto 5 febbraio 1891, n. 99. colquale, in esecuzione della legge 17 luglio 1890, n. 6972 (serie 3), si approvano i regolamenti sulle istituzioni pubbliche di beneficienza. URL: http://www.edizionieuropee.it/LAW/ HTML/0/zn10_01_001.html

6. Legge 3 giugno 1937, n. 847, Istituzione in ogni comune del regno dell'ente comunale di assistenza. URL: https:// www.gazzettaufficiale.it/atto/vediMenuHTML?atto.dataPubblicazioneGazzetta=1971-07-07 \&atto.codiceRedazi onale $=071 \mathrm{U} 0436 \&$ tipoSerie $=$ serie $\_$generale \& tipoVigenza $=$originario

7. Toniolo G. Trattato di economia sociale e scritti economici. Studium, 2000.

8. Дородонова, Н.В., Чилькина, К.В. Роль католической церкви в образовании международных организаций в сфере защиты и реализации социальных прав человека (первая треть XX в.)//Вестник Саратовской государственной юридической академии. 2020. № 4(135). С. 32.

9. Dr. Carl Levy. Review of Quine M. S. Italy's Social Revolution: Charity and Welfare from Liberalism to Fascism. Basingstoke, Palgrave, 2002. URL: https://reviews.history.ac.uk/review/385

10. Regio Decreto Legge 15 marzo 1923, n. 692, convertito dalla legge 17 aprile 1925, n. 473. URL: http://www. dottrinalavoro.it/wp-content/uploads/2014/07/RDL692-23.pdf

11. Killinger Ch. L. The History of Italy. London, 2002. P. 151.

12. Викулина Т.Д., Рязанова О.Е. Социальная система и её трансформация в условиях дискретного развития // Вопросы экономики и права. 2018. № 2(116). С. 27.

13. Perisco A. Il codice di Camaldoli. La DC e la ricerca della «terza via» tra Stato e mercato (1943-1993). La nascita del «mito di Camaldoli»//Journal of European Economic History. 2015. № 2. P. 228.

14. Damilano A. Atti e documenti della Democrazia cristiana (1943-1967). Rome, 1968. P. 1968.

15. Maurizio C. An Inconvenient Legacy: Corporatism and Catholic Culture from Fascism to the Republic//Tempo. 2019. № 1. P. 219-238. 